\title{
RESPONSE OF LUPINUS BRACTEOLARIS SEEDS TO PRE-GERMINATIVE TREATMENTS AND EXPERIMENTAL CONDITIONS
}

\author{
RESPOSTA DE SEMENTES DE LUPINUS BRACTEOLARIS \\ A TRATAMENTOS PRÉ-GERMINATIVOS \\ E CONDIÇÕES EXPERIMENTAIS
}

\author{
${ }^{1}$ Luciana Pinto Paim, ${ }^{2}$ Eduarda Demari Avrella \\ ${ }^{3}$ Juliana Carolina Alves Horlle, ${ }^{4}$ Claudimar Sidnei Fior \\ ${ }^{5}$ Marília Lazarotto, ${ }^{6}$ André Pich Brunes \\ 1 Master in Fitotecnia, Universidade Federal do Rio Grande do Sul, Porto Alegre, Brasil. \\ 2Doctorate in Fitotecnia, Universidade Federal do Rio Grande do Sul, Porto Alegre, Brasil. \\ ${ }^{3}$ Graduate student in agronomy, Universidade Federal do Rio Grande do Sul, Porto Alegre, Brasil. \\ ${ }^{4}$ Doctorate in Fitotecnia, Universidade Federal do Rio Grande do Sul, Porto Alegre, Brasil. \\ ${ }^{5}$ Doctorate in Forestry Engineering, Universidade Federal de Pelotas, Pelotas, Brasil. \\ ${ }^{3}$ Doctorate in Seed Science and Technology, Universidade Federal do Rio Grande do Sul, Porto Alegre, Brasil. \\ ${ }^{1}$ lucianappaim@bol.com.br, ${ }^{2}$ dudademari@hotmail.com, ${ }^{3}$ julianahorllee@gmail.com,
${ }^{4}$ Csfior@ufrgs.br, ${ }^{5}$ marilia.lazarotto@ufpel.edu.br, ${ }^{6}$ andre.brunes@gmail.com
}

Citación: Paim, L.P., Avrella, E.D., Horlle, J.C., Fior, C.S., Lazarotto, M., and Brunes, A.P. (2021). Response of Lupinus bracteolaris seeds to pre-germinative treatments and experimental conditions. Revista de Investigación Agraria y Ambiental, 12(2), 51 - 66. DOI: https://doi.org/10.22490/21456453.4278

\begin{abstract}
Contextualization: Lupinus bracteolaris is a heliophile species that vegetates lowlands, open slopes and sandstone hills.

Knowledge gap: Despite this great rusticity, there is little information about the species and its propagation, especially regarding the germination of its seeds.
\end{abstract}

Purpose: Evaluate the seeds of Lupinus bracteolaris, through pre-germinative treatments, substrate, temperature, luminosity, and water absorption, to understand the initial germination processes of the species.

Methodology: Fruits were collected from 20 matrix plants, then the seeds were processed and submitted to the following tests: Pregerminative methods (six treatments at 25 ${ }^{\circ} \mathrm{C}$; substrates and temperatures (sand and paper at 20, 25 and $30{ }^{\circ} \mathrm{C}$ ); photoblast test (white light, diffuse-green light and continuous dark under $20{ }^{\circ} \mathrm{C}$ ) and the imbibition curve (control and scarification between 
sandpaper under $20^{\circ} \mathrm{C}$ ). Evaluations: Percentage of germination and formed seedlings, germination speed index, average germination time and seedling formation, using a completely randomized design.

Results and conclusions: The results of the analyzed variables showed relevance for the pre-germinative treatment between sandpapers for 20 seconds, in addition, the substrate paper Germibox and the temperature of $20^{\circ} \mathrm{C}$ were the most suitable during the germination of the seeds of Lupinus bracteolaris, which were classified as neutral photoblastics and without dormancy.

Keywords: Luminosity; native lupine; seed germination; substrate; temperature; without dormancy

\section{RESUMO}

Contextualização: Lupinus bracteolaris é uma espécie heliófila que vegeta campos baixos, taludes descobertos e morros areníticos.

Lacuna de conhecimento: Apesar dessa alta rusticidade, há poucas informações sobre a espécie e a sua propagação, principalmente no que diz respeito à germinação de suas sementes.

Objetivo do estudo: Avaliar as sementes de Lupinus bracteolaris, por meio de tratamentos pré-germinativos, substrato, temperatura, luminosidade e absorção de água, para compreender os processos iniciais de germinação da espécie.

Metodologia: Coletaram-se frutos em 20 plantas matrizes, posteriormente realizou-se o beneficiamento das sementes e as submeteram aos testes: Métodos pré-germinativos (seis tratamentos sob $25^{\circ} \mathrm{C}$ ); substratos e temperaturas (areia e papel sob 20, 25 e $30{ }^{\circ} \mathrm{C}$ ); teste de fotoblastia (luz branca, luz verde difusa e escuro contínuo sob $20^{\circ} \mathrm{C}$ ) e a curva de embebição (controle e escarificação entre lixas sob $20^{\circ} \mathrm{C}$ ). Avaliações: Percentual de germinação e de plântulas formadas, índice de velocidade de germinação, tempo médio de germinação e de formação de plântulas, utilizando-se delineamento inteiramente casualizado.

Resultados e conclusões: Os resultados das variáveis analisadas mostraram relevância para o tratamento pré-germinativo entre lixas por 20 segundos, além disso, o substrato papel Germibox e a temperatura de $20^{\circ} \mathrm{C}$ foram os mais adequados durante a germinação das sementes de Lupinus bracteolaris, as quais foram classificados como fotoblásticos neutros e sem dormência.

Palavras-chave: Germinação de sementes; luminosidade; sem dormência; substrato; temperatura; tremoço nativo 


\section{GRAPHIC SUMMARY}

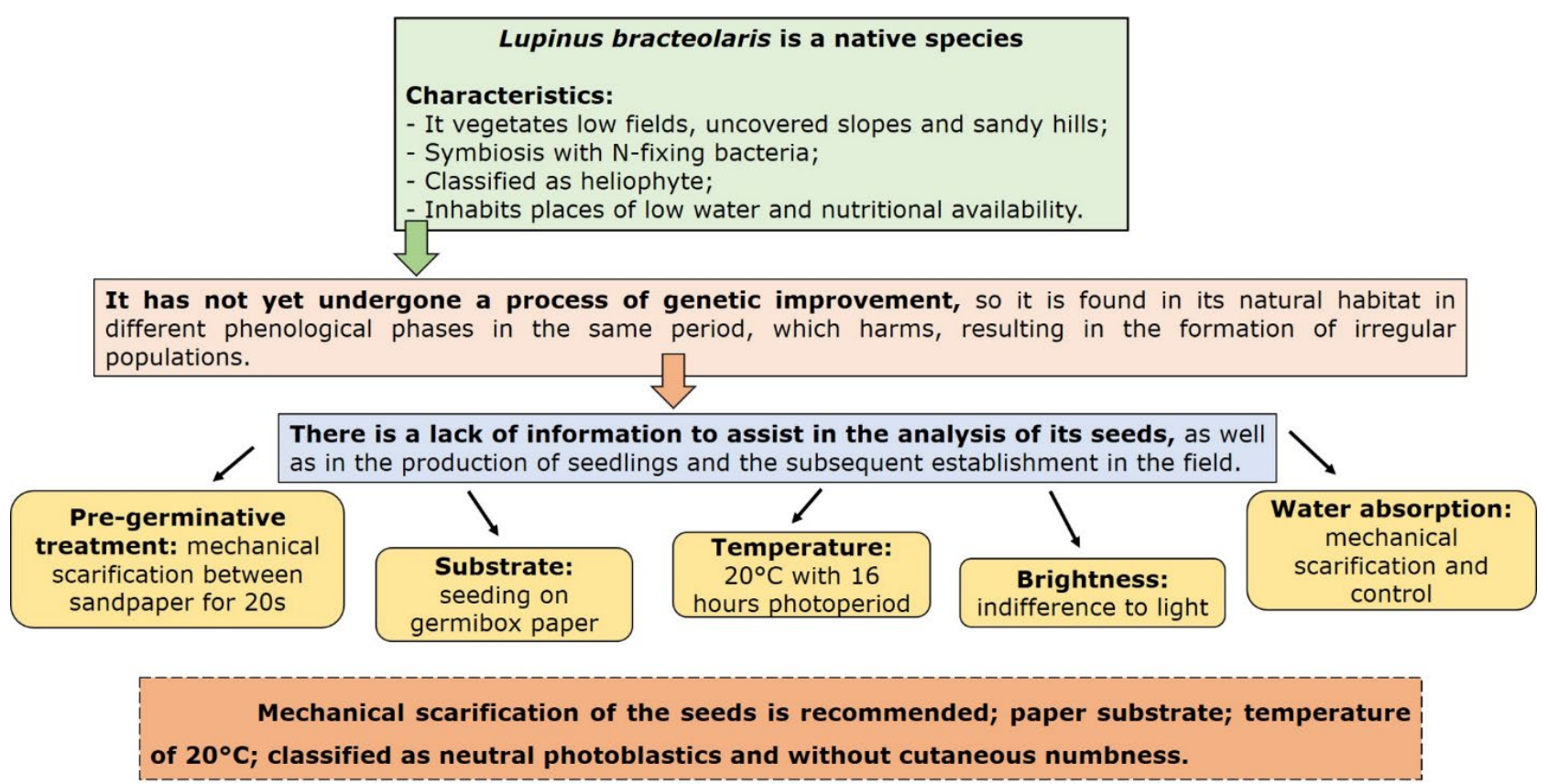

Source: authors

\section{INTRODUCTION}

Lupinus bracteolaris Desr. (= L. Czermakii Micheli) (Fabaceae) is an annual species popularly known as native lupine, with erect growth of 30 to $40 \mathrm{~cm}$ in height. It vegetates in places in full sun, granite and sandstone hills, lowlands and road slopes (Pinheiro and Miotto, 2001). It presents stem and leaf structures with many trichomes, favoring their development in places with low water availability, in addition to having active nodules in the roots; therefore, it shows the symbiosis with nitrogen-fixing bacteria. Due to these characteristics, it is assumed that the species has developed important strategies to survive in poor-sandy soils and adjacent to areas affected by sanding, which makes it promising for revegetation projects.

Similar to the species Lupinus albescens Hook. \& Arn., also native to the region of Rio Grande do Sul State (Paim et al., 2019), Lupinus bracteolaris can also be found in its natural habitat under different phenological phases; that is, some plants with the presence of flowers or fruits and/or seeds in the same period, which according to Cremonez et al. (2013), results in the formation of irregular populations. There is little information available in the literature about this species, especially on its propagation and regarding seed germination. To allow recommendations for the application of plants of this species in the field, or for seedling production, studies on the need for pre-germinative treatments and environmental conditions that accelerate and standardize the initial germination processes are necessary.

Lupinus bracteolaris presents seeds with a hard and resistant tegument, therefore, it is believed that the use of pre-germinative treatments may favor the increase of their permeability to water and gases, according to Guedes et al. (2013), allowing the beginning of germination processes. Pre-germination treatments contribute not only to rapid seed 
germination, but also to a higher efficiency in the uniformity of seedling establishment in adverse environments (Santos et al., 2011). In addition, the proper use of substrate and temperature in seed germination may favor the speed and percentage of germinated seeds, because the substrate acts to retain sufficient amounts of water and oxygen, and the temperature activates certain biochemical reactions during germination processes (Ministério da Agricultura, 2009, Taiz et al., 2017). According to Marcos Filho (2015), the correct knowledge of these factors will result in the expression of the maximum germination potential in a shorter period of time.

Besides humidity and temperature, the presence and intensity of light is of great influence on the life cycle of plants. Those factors directly affect the percentage and speed of germinated seeds (Cosmo et al., 2017). The plants can be positively or negatively influenced by light. Thus, the seeds can be classified as aphotoblastic or neutral (germination indifferent to light), positive photoblastic (greater germination under light) and negative photoblastic (greater germination in the dark) (Kerbauy, 2008). Therefore, it is essential to use methods adjusted for each species, since this may optimize propagation, reducing emergence failures and/or maximizing seedling formation (Lessa et al., 2013)
Specific studies on pre-germination methods, substrates, temperatures, luminosity and water absorption by seeds are extremely important, especially in species that are little explored and that may act in the restoration of degraded environments, as most native species. As a result, the objective of this work was to evaluate the seeds of Lupinus bracteolaris, through pre-germinative treatments, substrate, temperature, luminosity, and water absorption, to understand the initial germination processes of the species.

\section{MATERIALS AND METHODS}

\section{Seed collection and processing}

In December 2015, Lupinus bracteolaris fruits (Figure 1A) were collected from approximately 20 matrix plants in situ, close to an arenization core (Figure 1B) in the municipality of São Francisco de Assis, State of Rio Grande do Sul

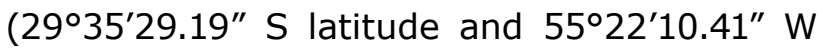
longitude) (Figure 1C). The weather in the region is characterized as humid subtropical of the Cfa-type, according to the classification of Köppen, with an average annual rainfall of $1,750 \mathrm{~mm}$, well distributed. The average temperature of the coldest month varies between -3 and $18{ }^{\circ} \mathrm{C}$, and the warmest month it exceeds $22{ }^{\circ} \mathrm{C}$ (Alvares et al., 2013). 


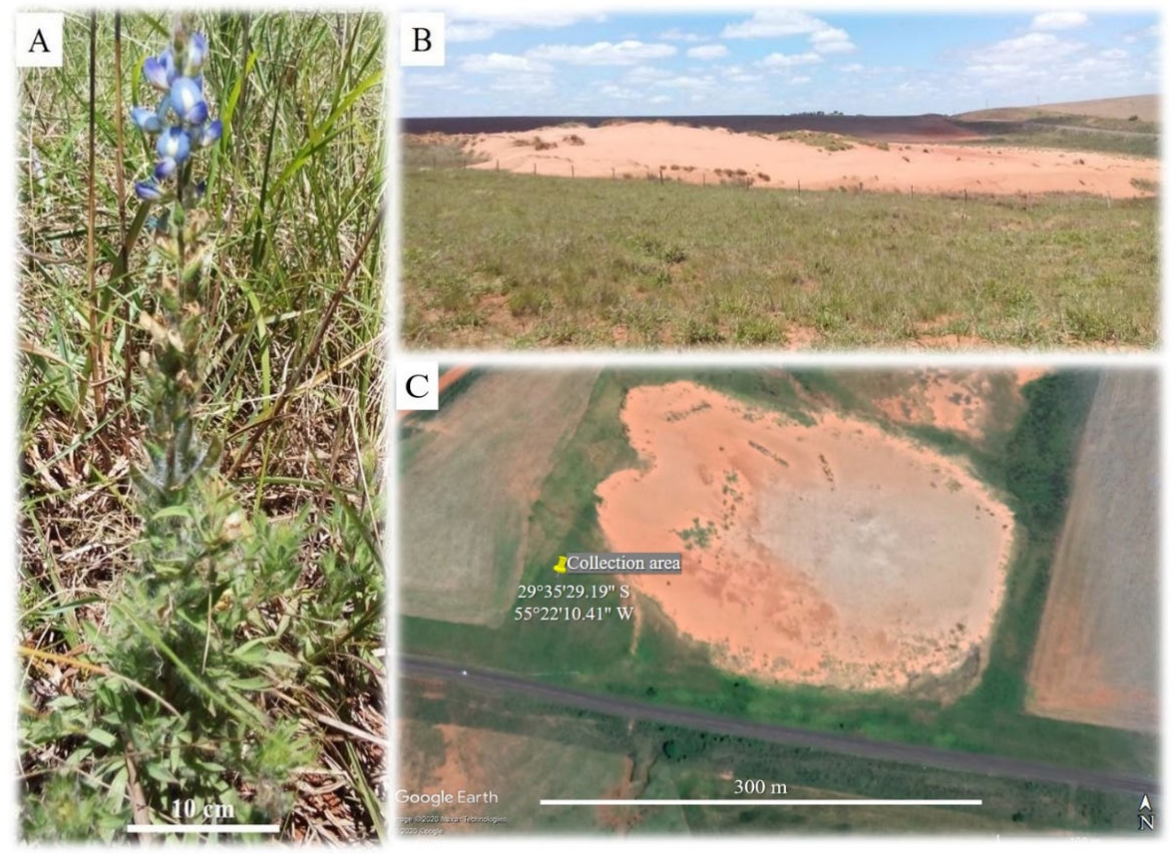

Figure 1. A Lupinus bracteolaris specimen in situ (A), collected near an arenization focus (B), the area located in the municipality of São Francisco de Assis-RS (C). Source: Google Earth, 2018.

After the collection, the fruits were taken to the Horticulture Biotechnology Laboratory of the Department of Horticulture and Silviculture of the Federal University of Rio Grande do Sul (UFRGS) in Porto Alegre, RS. They were placed on a greenhouse bench with $70 \%$ of light interception, without temperature and relative humidity control, for drying and finishing dehiscence. At the end of the process, the seeds were processed through manual collection and homogenization in only one batch.

This batch of seeds was submitted to water content evaluation, in three $0.5 \mathrm{~g}$ replicates, using the method of percentage difference in mass after drying in an oven at $105 \pm 3^{\circ} \mathrm{C}$ until constant weight (Ministério da Agricultura, 2009). Later, during the execution of the tests, the seeds were packed in $2.0 \mathrm{~L}$ transparent polyethylene bags, with a zip-type closure system, each bag with about $500 \mathrm{~mL}$ of seeds. Then, the seeds remained at a temperature of 5 to $8^{\circ} \mathrm{C}$, in a household fridge.
In all tests, before sowing, the seeds were submitted to the disinfestation process through immersion in $70 \%(\mathrm{v} / \mathrm{v})$ ethanol for 30 seconds, followed by sodium hypochlorite $2.0 \%$ (a.i.), with $0.01 \%$ concentrated detergent (Tween $20 \AA$ ), for 10 minutes. To remove residues from these disinfestation agents, three rinses were performed in autoclaved deionized water.

\section{Pre-germinative treatments}

The seeds were subjected to six treatments: Control (T1); mechanical scarification between sandpaper No. 120 for 20 and 40 seconds (T2 and T3); immersion in water $(500 \mathrm{ml})$ for 24 hours at an ambient temperature of $\pm 25^{\circ} \mathrm{C}$ (T4); thermal shock in water at $50{ }^{\circ} \mathrm{C}$ and 100 ${ }^{\circ} \mathrm{C}$ for 10 minutes until cool in an ambient temperature of $\pm 25^{\circ} \mathrm{C}$ (T5 and T6). Subsequently, the seeds were placed to germinate in a BOD-type incubator chamber with a constant temperature of $25^{\circ} \mathrm{C}$. 
The pre-germinative treatment by the method of mechanical scarification between sandpaper No. 120 followed the methodology recommended for Lupinus albescens native species in the work of Paim et al. (2019).

\section{Substrates and temperatures}

The seeds used in this test were previously treated with mechanical scarification between sandpaper No. 120 for 20 seconds, due to its easy execution and the highlight for most of the analyzed variables, after which they were sown on the substrates sand and paper. These treatments were carried out at temperatures of 20, 25 and $30^{\circ} \mathrm{C}$, in a BOD-type incubator chamber.

\section{Photoblastic test}

Seeds scarified between sandpaper No. 120 for 20 seconds were sown on paper and kept at a constant temperature of $20{ }^{\circ} \mathrm{C}$ in a BODtype incubator chamber. The light conditions were: White light, diffuse green light (with an intensity of 1,300 lux) and absence of light. In light treatments, the irradiance was approximately $30 \mu \mathrm{molm}^{-2} \mathrm{~s}^{-1}$. The white light was provided by fluorescent lamps (30 W), the diffuse green light was obtained by wrapping the transparent-plastic Gerboxes with green cellophane paper (double layer, juxtaposed), while in the treatment with absence of light, the boxes were wrapped in aluminum foil and packed in a cardboard box, aiming to totally prevent the incidence of light in the seeds during the germination process.

\section{Imbibition curve}

Seeds submitted to the control treatments (without scarification) and mechanical scarification between sandpaper No. 120 for 20 seconds were sown on paper and taken to the environment with a constant temperature of $20^{\circ} \mathrm{C}$ in a BOD-type incubator chamber.
During the imbibition monitoring, the seeds were evaluated by means of successive weighing every 2 hours, for the first 12 hours and every 12 hours until $50 \%$ of the seeds of each repetition showed radicle protrusion. At each weighing, the seeds were removed from the Gerboxes, placed on paper towels to remove the excess of water and weighed on a precision scale $(0.001 \mathrm{~g}$ capacity). After weighing, the seeds returned to their respective boxes and remained under a controlled environment. After the last weighing, the water content of the seeds was determined (Ministério da Agricultura, 2009).

The percentage increase in mass in relation to the initial mass, for each evaluation time was calculated through the formula:

Formula 1: Mass gain $(\%)=\frac{\text { Final mass }(g)}{\text { initial mass }(g)} \times 100$

The sowing of the tests above occurred on Germibox paper, with the exception of the substrate by temperature test, which was on sand. In each replicate, a sheet (previously sterilized in an autoclave for 20 minutes) was used, moistened with autoclaved deionized water at the proportion of 2.5 times the dry paper mass (Ministério da Agricultura, 2009).

The papers were packed in transparent plastic Gerbox, which were individually arranged in transparent polyethylene bags, that is, to avoid excessive respiration. When sand was used as a substrate, it was previously autoclaved and at the time of sowing, hydrated with autoclaved deionized water up to $60 \%$ of the water holding capacity (Ministério da Agricultura, 2009).

All experiments were conducted under a 16hour photoperiod of light in incubator chambers of the BOD type (Biochemical Oxygen Demand). The tests described below are in the chronological phase of execution. 
The evaluations of all the tests described above consisted of the daily count of the number of germinated seeds and normal seedlings formed, except in the treatment with absence of light from the photoblast test, which was developed at the end of the experiment. The parameter used in germination was the protrusion of the radicle and in the formation of seedlings, those that had a normal aerial part and root system formed (Ministério da Agricultura, 2009).

At the end of the analysis period, when in three consecutive evaluations there was no emergence and seedling formation, approximately on the $18^{\text {th }}$ day, after the installation of the experiment, the following variables were calculated: Germination percentage (G) and formed seedlings (FS), according to the total of normal seedlings; the germination speed index (GSI), according to the formula suggested by Maguire (1962); the average germination time (AGT) and the average seedling formation time (SFT), according to the formula proposed by Silva and Nakagawa (1995). The calculated variables were as follows:

\section{Germination (G) and formed seedlings (FS):}

Formula 2: $\mathrm{G}$ or $\mathrm{FS}=\frac{\mathrm{N}}{100} \mathrm{X} 100$

Where: $\mathrm{N}=$ Number of seeds germinated at the end of the test. Unity: \%.

\section{Germination speed index (GSI):}

Formula 3: $\quad \mathrm{GSI}=\sum \frac{\mathrm{ni}}{\mathrm{ti}}$

Where: $\mathrm{ni}=$ number of seeds that germinated in time ' $\mathrm{i}$ '; $\mathrm{ti}=$ time after installation of the test; $\mathrm{i}=1 \rightarrow 18$ days. Unity: Dimensionless.

\section{Average germination time (AGT):}

Formula 4: $\mathrm{AGT}=\frac{\sum \text { niti }}{\sum \text { niti }}$

Where: $\mathrm{ni}=$ number of seeds germinated per day; $\mathrm{ti}=$ incubation time; $\mathrm{i}=1 \rightarrow 18$ days. Unit: Days.

The experimental design used in this study was the completely randomized (CRD), in a singlefactor scheme for the tests of pre-germinative treatments, photoblastism and water absorption curve. The substrate and temperature test were performed in a two-factor arrangement $(2 \times 3)$, where the first factor was the substrates sand and paper, and the second the temperatures of 20,25 and $30^{\circ} \mathrm{C}$. For all the tests above, four replicates of 25 seeds were used, totaling 100 seeds per treatment, with the exception of the photoblast test, in which five replicates were used.

\section{Statistical Analysis}

The data were submitted to Bartlett's normality test and, after analysis of variance (ANO$\mathrm{VA}$ ), followed by comparison of means through the MSD test (Minimum Significant Difference) at the level of $5 \%$ probability of error, using the features of CoStat 6.4 software. Being that, when the tests were performed with two factors, the analysis of variance was tested to verify the interaction between the factors.

\section{RESULTS AND DISCUSSION}

On the day following the collection, the seeds of Lupinus bracteolaris had a water content of $6.82 \%$. Thus, the seeds from the field showed a very low value, possibly indicating that the degree of seed maturity was nearing completion. In the laboratory, the completion of the seed maturation process was observed in only 15 days, by changing the color of the vegetables from gray-yellow to totally dark gray, in addition to opening all the vegetables and releasing the seeds. These results show the 
importance of determining the water content, in order to assist in the interpretation of the maturation phases of the seeds collected in the field. Particularly, in the case of species with little information available in the literature, as is the case of Lupinus bracteolaris, and mainly because the seeds collected in natural populations are in different phenological stages, some plants with the presence of flowers or fruits and/or seeds, providing irregular phases within the same population.

\section{Pre-germinative treatments}

The first study carried out to accelerate the germination phase of Lupinus bracteolaris seeds showed superior results in the T2 treatment (mechanical scarification with sandpaper No. 120, for 20 seconds), for the variables: Germination percentage, seedling formation and speed index germination (Table 1) but did not differ statistically from treatment T3 (mechanical scarification with sandpaper No. 120 for 40 seconds).

Table 1. Average percentage of germination (G) and seedling formation (SF), germination speed index (GSI), average germination time (AGT) and seedling formation time (SFT), under six pre-germination treatments to accelerate the germination process of Lupinus bracteolaris seeds.

\begin{tabular}{|c|c|c|c|c|c|c|}
\hline Treatment & Description & G (\%) & SF (\%) & GSI & AGT (days) & SFT (days) \\
\hline $\mathrm{T} 1$ & Control & $19 \mathrm{~b}$ & $19 \mathrm{~b}$ & $0.99 b$ & $6.65 \mathrm{abc}$ & $9.80 \mathrm{a}$ \\
\hline $\mathrm{T} 2$ & $\begin{array}{l}\text { MSS for } 20 \\
\text { seconds }\end{array}$ & $80 a$ & $80 a$ & $4.41 \mathrm{a}$ & $8.19 \mathrm{c}$ & $13.39 \mathrm{~b}$ \\
\hline T3 & $\begin{array}{l}\text { MSS for } 40 \\
\text { seconds }\end{array}$ & $78 \mathrm{a}$ & $78 \mathrm{a}$ & $3.88 \mathrm{a}$ & 8.44 bc & $13.17 b$ \\
\hline $\mathrm{T} 4$ & $\begin{array}{l}\text { IW for } 24 \\
\text { hours at room } \\
\text { temperature) }\end{array}$ & $20 \mathrm{~b}$ & $20 \mathrm{~b}$ & $1.47 \mathrm{~b}$ & $6.23 \mathrm{a}$ & $8.58 \mathrm{a}$ \\
\hline T5 & $\begin{array}{l}\text { IW at } 50^{\circ} \mathrm{C} \\
\text { for } 10 \text { minutes }\end{array}$ & $18 \mathrm{~b}$ & $18 \mathrm{~b}$ & $0.87 b$ & $5.55 a b$ & $9.96 \mathrm{a}$ \\
\hline T6 & $\begin{array}{l}\text { IW at } 100^{\circ} \mathrm{C} \\
\text { for } 10 \text { minutes }\end{array}$ & $17 \mathrm{~b}$ & $17 \mathrm{~b}$ & $0.77 b$ & $5.72 a b$ & $9.86 \mathrm{a}$ \\
\hline \multicolumn{2}{|l|}{ CV (\%) } & 18.81 & 18.61 & 29.40 & 19.02 & 14.82 \\
\hline \multicolumn{2}{|l|}{ Value $p$} & $P<0.001$ & $P<0.001$ & $P<0.001$ & $P=0.0402$ & $P<0.01$ \\
\hline \multicolumn{2}{|c|}{ Transformed data } & - & - & - & Asen & - \\
\hline
\end{tabular}

MSS = mechanical scarification between sandpaper No. 120; IW = immersion in water; CV = coefficient of variation In the column, means followed by the same letters do not differ, by the DMS test $(p<0.05)$.

Source: Authors.

In other species from the same family, the method of mechanical scarification with sandpaper also showed superior results in the seed germination processes, as well as a high rate of germination speed, as for Schizolobium parahyba (Vell.) Blake (Pereira et al., 2011) and Lupinus albescens (Paim et al., 2019). This is mainly due to the fact that mechanical scarification causes cracks in the tegument of the seeds, therefore increasing the permeability to water and gases, promoting the beginning of imbibition processes and, consequently, germination (Carvalho and Nakagawa, 2012, Guedes et al., 2013). 
Thus, seed scarification becomes a highly relevant method to standardize and increase germination speed. In addition, it is an important technique in the germination of other native species, such as Macroptilium martii Benth. (Araújo et al., 2014a) and Lupinus albescens (Paim et al., 2019), Fabaceae species that inhabit extreme areas of low water availability and poor soils in the Caatinga and Pampa biomes, respectively.

The comparison between the results of the seed treatments, with the locals of occurrence of the species Lupinus bracteolaris and Lupinus albescens (Paim et al., 2019), that is, sandy soils of arenitic origin, shows that the results found, under the ecophysiological aspect, corroborate the work of Rovedder et al. (2010), in which the authors mention that the propagules dispersed in these environments are susceptible to the action of wind and water erosive processes, which contributes to the rupture in the seed tegument, simulating a mechanical scarification resulting from the sand abrasion effects.

The average time of germination and seedling formation showed shorter periods for treatment T4 (immersion in water for 24 hours at room temperature) (Table 1); nevertheless, the application of this treatment becomes impracticable, since the average of germinated seeds was only $20 \%$. A shorter average germination time is justified in the T4 treatment due to the fact that the few seeds that germinated in a short period of time had a permeable tegument. Because the treatment was not effective in overcoming the physical barrier to germination, the seeds able to germinate were pre-soaked and started the germination process during the treatment.

According to the results obtained in the pregerminative treatment test, where, for most of the variables analyzed, the treatment regarding scarification between sandpapers was superior, in addition to its easy execution, it was adopted as the standard for further experiments.

\section{Substrates and temperatures}

The analysis of variance showed interaction between the two factors for the variables of germination percentage and seedling formation, as well as for the average germination time (Table 2). For the germination speed index and the average time of seedling formation, there was no interaction between temperatures and substrates, with a significant effect only for these factors analyzed separately (Table 2).

Table 2. Analysis of variance for germination percentage (G), seedling formation (SF), average germination time (AGT), seedling formation time (SFT) and germination speed index (GSI) under three temperatures and two substrates in Lupinus bracteolaris seeds.

\begin{tabular}{l|c|c|c|c|c}
\hline Value & $\mathbf{G}$ & $\mathbf{G}$ SF (\%) & AGT (days) & SFT (days) & GSI \\
\hline Substrates & $\mathrm{P}<0.001$ & $\mathrm{P}<0.001$ & $\mathrm{P}<0.001$ & $\mathrm{P}<0.021$ & $\mathrm{P}<0.001$ \\
\hline Temperatures & $\mathrm{P}<0.04$ & $\mathrm{P}<0.004$ & $\mathrm{P}<0.001$ & $\mathrm{P}<0.001$ & $\mathrm{P}<0.003$ \\
\hline Interaction & $\mathrm{P}<0.001$ & $\mathrm{P}<0.001$ & $\mathrm{P}<0.021$ & $\mathrm{P}=0.323^{\mathrm{ns}}$ & $\mathrm{P}=0.642^{\mathrm{ns}}$ \\
\hline CV (\%) & 14.12 & 15.47 & 13.37 & 12.27 & 18.70 \\
\hline Overall Average & 74 & 72 & 8 & 13 & 4 \\
\hline
\end{tabular}

$\mathrm{CV}=$ coefficient of variation. ${ }^{\mathrm{ns}}=$ not significant at $5 \%$ probability of error. 
The germination percentage did not differ significantly in the sand substrate for temperatures of 20 and $25{ }^{\circ} \mathrm{C}$, reaching 79 and $70 \%$ of germinated seeds, respectively; this is also observed in the variable seedling formation, at both temperatures (Table 3). It was observed that the lower temperatures promoted the germination and the formation of seedlings in the sand substrate, because the highest temperature tested $\left(30^{\circ} \mathrm{C}\right)$ resulted in non-germinated seeds and seedlings with malformation; specifically, essential structures of the aerial part and root with reduced size.

In the case of the paper substrate, no significant differences were found between the temperatures tested, with an overall mean of 84 $\%$ for germination and seedling formation ( $\mathrm{Ta}$ ble 3). Likewise, the species Dioclea violaceae Mart. (Zucareli et al., 2010) presented similar results when the seeds were submitted to temperatures of 20,25 and $30^{\circ} \mathrm{C}$, using the paper substrate. As a result, the paper stood out as an important substrate for these species, as it provided germination at all temperatures evaluated, with no identification of critical temperatures at this stage. According to Pilau et al. (2012), the knowledge of temperature and substrate factors are fundamental in the beginning of germination processes, due to the peculiar characteristics among the species.

The average germination time is an easily measured variable that can be used to determine the vigor of the seeds, as according to Carvalho et al. (2012) a rapid germination and seedling emergence are important attributes for the formation of quality seedlings. For $\mathrm{Lu}$ pinus bracteolaris seeds, there was a shorter average germination time in the sand substrate at $20^{\circ} \mathrm{C}$ ( 6.85 days), while on paper, the shortest time was for temperatures of 20 and $25{ }^{\circ} \mathrm{C}$, with an average of 5.91 and 6.15 days, respectively (Table 3 ).

In both substrates (sand and paper), it was found that the lowest temperatures (20 and $25{ }^{\circ} \mathrm{C}$ ) promoted accelerated germination of seeds. It is assumed that mild temperatures may have triggered certain biochemical reactions during the germination process, which boosted specific enzyme systems (Marcos Filho, 2015).

Table 3. Germination percentage (G) of seedling formation (SF) and average germination time (AGT), under three temperatures and two substrates in Lupinus bracteolaris seeds.

\begin{tabular}{l|c|c|c|c}
\hline Temperatures & Substrates & G (\%) & \multicolumn{1}{c}{ SF (\%) } & AGT (days) \\
\hline $20^{\circ} \mathrm{C}$ & & $79 \mathrm{Aa}$ & $79 \mathrm{Aa}$ & $6.85 \mathrm{Aa}$ \\
\hline $25^{\circ} \mathrm{C}$ & Sand & $70 \mathrm{Aa}$ & $70 \mathrm{Aa}$ & $10.38 \mathrm{Ba}$ \\
\hline $30^{\circ} \mathrm{C}$ & & $45 \mathrm{Bb}$ & $31 \mathrm{Bb}$ & $11.5 \mathrm{Ba}$ \\
\hline $20^{\circ} \mathrm{C}$ & & $83 \mathrm{Aa}$ & $83 \mathrm{Aa}$ & $5.91 \mathrm{Aa}$ \\
\hline $25^{\circ} \mathrm{C}$ & & $81 \mathrm{Aa}$ & $81 \mathrm{Aa}$ & $6.15 \mathrm{Ab}$ \\
\hline $30^{\circ} \mathrm{C}$ & Paper & $86.7 \mathrm{Aa}$ & $86.7 \mathrm{Aa}$ & $8.13 \mathrm{Bb}$ \\
\hline
\end{tabular}

Averages of temperatures followed by uppercase letters and means of substrates followed by lowercase letters, do not differ by the DMS test $(p<0.05)$.

Source: Authors. 
The highest rate of germination speed of 5.79 was found for the paper substrate, in addition, this substrate also provided a shorter average time for seedling formation, with an average of 11.64 days (Table 4). The paper substrate also provided satisfactory germination speed index results in works with other species, such as for Albizia edwallii (Hoehne) Barneby \& J. W. Grimes (Duarte et al., 2015) and Anadenanthera peregrina (L.) Speg. (Miranda et al., 2012).

Therefore, the paper substrate was more successful for a greater number of variables during the germination and seedling formation of the Lupinus bracteolaris species. It should be observed that the use of an appropriate substrate has a great influence on the germination of species, as is the case with paper, which is the most used in the tests and it has the advantage of maintaining constant humidity for long periods (Ministério da Agricultura, 2009). This is very important as the size of the seed can change the requirement for the amount of water, as well as the sensitivity or not to light and the ease in the course of seedling analysis (Ministério da Agricultura, 2009).

Table 4. Germination speed index (GSI) and the average seedling formation time (SFT) of Lupinus bracteolaris sown on two substrates and in an environment with three temperature regimes.

\begin{tabular}{|c|c|c|c|c|c|}
\hline Substrates & GSI & SFT (days) & Temperatures & GSI & SFT (days) \\
\hline \multirow{2}{*}{ Paper } & \multirow{2}{*}{$5.79 a$} & \multirow{2}{*}{$11.64 \mathrm{a}$} & $20^{\circ} \mathrm{C}$ & $5.40 \mathrm{a}$ & $11.25 \mathrm{a}$ \\
\hline & & & $25^{\circ} \mathrm{C}$ & $3.96 b$ & $14.49 \mathrm{~b}$ \\
\hline Sand & $2.67 \mathrm{~b}$ & $14.98 b$ & $30^{\circ} \mathrm{C}$ & $2.98 \mathrm{c}$ & $14.55 \mathrm{~b}$ \\
\hline CV (\%) & 18.70 & 12.27 & CV (\%) & 18.70 & 12.27 \\
\hline Value $p$ & $P<0.001$ & $P<0.01$ & Value $p$ & $P<0.01$ & $P<0.01$ \\
\hline
\end{tabular}

Source: Authors

In relation to temperatures, the treatment of $20^{\circ} \mathrm{C}$ showed superior results for the variable germination speed index with a value of 5.40, moreover, this temperature also had a shorter average time of seedling formation, this being 11.25 days (Table 4 ), resulting in suitable conditions for Lupinus bracteolaris seeds to express their vigor. Knowing the optimal temperature in relation to the maximum or minimum becomes important, since extreme temperatures imply a reduction in the speed of germination processes, causing the exposure of seedlings to adverse factors for long periods, which can lead to reduction of the germination rate (Baskin and Baskin, 2014).
Low temperatures delay the germination and growth of seedlings, due to the reduction in the activities of enzymes involved in respiration and metabolism (Marcos Filho, 2015); However, in relation to Lupinus bracteolaris, laboratory results have shown that mild temperatures benefit the species, so it appears that in the field, its germination phase coincides naturally with a period of lower temperatures.

It was found that the temperature of $20^{\circ} \mathrm{C}$ was the most relevant and promising in the germination of Lupinus bracteolaris, in the same way as the use of the paper substrate. These two factors showed greater adequacy 
in the germination of the species, according to most of the variables analyzed and the visualization of fewer fungi in the seeds, resulting in the formation of healthy seedlings and of uniform size (aerial part and roots).

\section{Photoblast}

The results of the photoblast test did not highlight significant differences between treatments for the percentage of seed germination (Table 5). It is likely that the characteristics of the species promoted its germination in wide light conditions, thus providing the development of phenotypic plasticity, allowing to classify Lupinus bracteolaris seeds as neutral photoblastic. Similar results were also found for Lupinus albescens, another species native to the sands region (Paim et al., 2019).

Table 5. Germination percentage of Lupinus bracteolaris seeds under different light conditions.

\begin{tabular}{l|c}
\hline Treatments & Germination (\%) \\
\hline Green light & 87 \\
\hline Continuous dark & 77 \\
\hline White light & 76 \\
\hline $\mathrm{CV}$ & 12.37 \\
\hline Value p & $0.1937^{\mathrm{ns}}$ \\
\hline
\end{tabular}

$\mathrm{CV}=$ coefficient of variation. ${ }^{\mathrm{ns}}=$ not significant at $5 \%$ probability of error.

Source: Authors

\section{Water absorption curve}

Imbibition was observed in both the control and the pre-germinative treatments with mechanical scarification for 20 seconds; however, only the scarified seeds showed a higher mass gain in less time in the three stages of germination (Figure 2). Therefore, it was observed that only the seeds submitted to the pre-germinative treatment followed the three-phase pattern mentioned by Marcos Filho (2015), but the imbibition in the control treatment indicates the absence of physical dormancy in the seeds of the species.

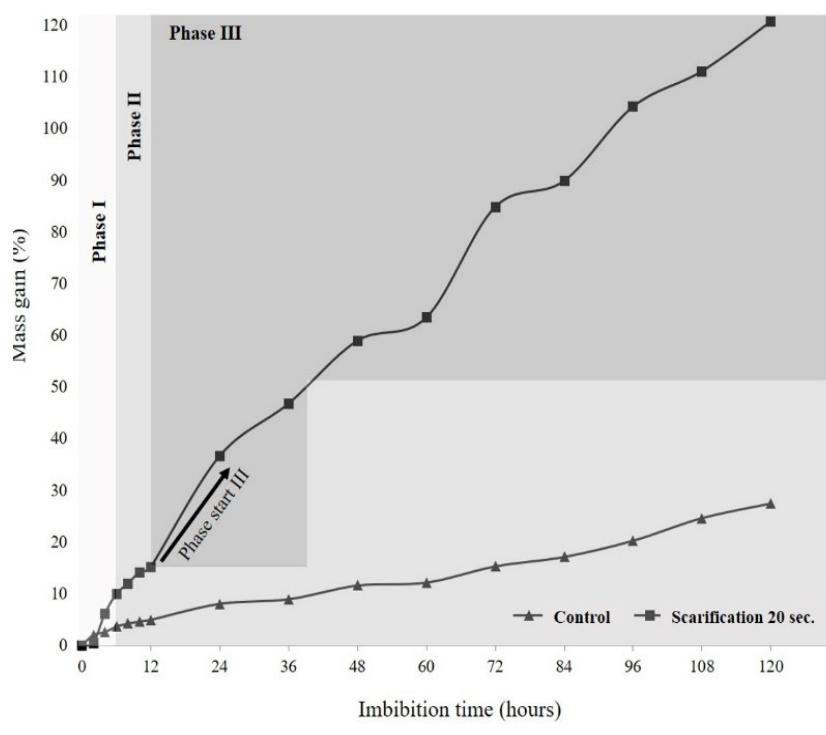

Figure 2. Water absorption curve in Lupinus bracteolaris seeds under pre-germinative treatment with mechanical scarification for 20 seconds and control (without scarification).

Source: Authors

The three-phase pattern presents important phases for the germination process, from water imbibition by the seeds to the beginning of the growth of the embryo. Thus, it was observed that after soaking, the scarified seeds absorbed water rapidly, reaching a level of approximately $12 \%$ increase in mass, after 8 hours (phase I), about $67 \%$ more than the control in this same period. This first imbibition phase is a consequence of the difference in water potential of the seed and the medium, this is a physical process in which the seed absorbs water for its rehydration until it reaches the equilibrium point, which does not depend on the viability of the seeds and the length of stay varies from species to species (Marcos Filho, 2015). 
The second phase is known as stationary, preparatory biochemistry or growth-inducing, which will activate the degradation of reserves that will be used as an energy source for the reactivation of the embryo (Portes et al., 2018). There is usually a reduction in water absorption and in the respiratory processes (Araújo et al., 2014a) in this phase, as occurred in the Lupinus bracteolaris seeds which gained only $3 \%$ in a period of 4 hours. Nevertheless, water absorption and mass gain were observed due to the treatment with mechanical scarification providing the opening of channels and the removal of the waxy layer, which promoted the entry of water at a greater speed, a fact that shows the lack of dormancy in the species seeds. According to Araújo et al. (2014b), seeds with dormancy may present this phase longer and with low mass gain.

The third phase started after 12 hours, with an increase in water absorption and a $60 \%$ mass gain in the seeds in relation to phase II, consequently, beginning the protrusion of the radicle in this phase. Oliveira and Bosco (2013) corroborate that, at this stage there is an increase in the water content of the seeds and the emission of primary root. Therefore, the three-phase process of germination of $\mathrm{Lu}$ pinus bracteolaris seeds was completed in 120 hours, when $50 \%$ of the seeds of each repetition germinated.

The duration of each phase of germination can vary according to the tegument permeability and the size of the seed, as well as the conditions used during the imbibition process, such as temperature and substrate (Carvalho and Nakagawa, 2012). In view of this, the absorption curve showed that there was imbibition in both treatments, which allows us to conclude that the seed coat of Lupinus bracteolaris does not present impermeability, it just needs a longer period for the imbibition process. Thus, it is evident that the use of pre-germinative treatment with mechanical scarification accelerates the absorption of water, and, consequently, the germination processes. due to the opening of channels on the tegument. This method causes small fractures in the seed tegument, favoring greater permeability during imbibition and, thus, water absorption occurs more rapidly through tissues and speeds up the depletion of endosperm reserves (Shimizu et al. 2011).

Most species belonging to the Fabaceae family commonly develop seeds of impermeable and resistant integuments, acting as barriers in the absorption of water and subsequent biochemical reactions inside it. However, it is a condition that limits the germination of many plant species. Nevertheless, seeds that germinate in less than 28 days of sowing under natural conditions of the environment are not considered with integumentary dormancy (Baskin and Baskin, 2014). Therefore, the results of this work indicate that the seeds of the native species Lupinus bracteolaris have no tegument dormancy, due to the fact that germination occurs naturally in less than 28 days.

In addition, the different species belonging to the genus Lupinus (American, European and African) are considered as highly tolerant to dry habitats and poor nutrient soils (Elbandy and Rho, 2014; Martínez Alcalá et al. 2010). Therefore, some natives of this group can be denominated pioneers, as they are the first to colonize newly-impacted and/or disturbed soils; namely, soil with little vegetation and exposed to adverse edaphoclimatic factors (light, rain, wind, soil, etc.). This information is in line with observations made in this study, as the collection sites of Lupinus bracteolaris seeds are commonly sunny, low fields, slopes of roads with exposed soil and areas adjacent to sandy soils. 


\section{CONCLUSIONS}

Lupinus bracteolaris shows a positive response to pre-germinative treatment through mechanical scarification of its seeds, indicating a limitation in water absorption due to the semipermeable resistance of the propagule casings.

For the analysis of its seeds, the substrate paper Germibox and the temperature of $20^{\circ} \mathrm{C}$ are the most appropriate among those tested, reaching the formation of normal seedlings about 11 days after the beginning of the test.

Lupinus bracteolaris seeds can be classified as neutral photoblastic and, although there is no tegument dormancy, water absorption is slow in the absence of a scarification treatment.

\section{AUTHOR'S CONTRIBUTION}

First author: Methodology, research, data analysis and original draft writing. Second author: Methodology, research and original draft writing. Third author: Research and original draft writing. Fourth author: Review and editing. Fifth author: Review and editing. Sixth author: Review and editing.

\section{ACKNOWLEDGMENTS}

The present study was carried out with support from CAPES (Higher Education Personnel Improvement Coordination), CNPq (National Council for Scientific and Technological Development) and FAPERGS (Foundation for Research Support of the State of Rio Grande do Sul) that contributed to the development of the work.

\section{LITERATURE CITED}

Alvares, C.A., Stape, J.L.; Sentelhas, P.C.; Gonçalves, J.L.M. and Spavorek, G. (2013). Köppen's climate classification map for Brazil. Meteorologische Zeitschrift, 22(6), 711-728. http://dx.doi. org/10.1127/0941-2948/2013/0507
Araújo, A.M.S.; Torres, S.B.; Nogueira, N.W.; Freitas, R.M.O. and Carvalho, S.M.C. (2014a). Caracterização morfométrica e germinação de sementes de Macroptilium martii BENTH. (Fabaceae). Revista Caatinga, 27(3), 124-131.

Araújo, R.F.; Zonta, J.B.; Araújo, E.F.; Donzeles, S.M.L. and Costa, G.M. (2014b). Curva de absorção de água em sementes de pinhão-manso (Jatropha curcas L.). Idesia, 32(2), 5-10. http:// dx.doi.org/10.4067/S0718-34292014000200002

Baskin, C.C. and Baskin, J.M. (2014). Seeds: Ecology, Biogeography, and Evolution of Dormancy and Germination. San Diego: Elsevier Science \& Technology Books.

Carvalho, N.M. and Nakagawa, J. (2012). Sementes: ciência, tecnologia e produção. Jaboticabal: FUNEP.

Carvalho, T.C.; Grzybowski, C.R.S.; Ohlson, O.C. and Panobianco, M. (2012). Comparação da qualidade fisiológica de sementes de soja convencional e de sua derivada transgênica. Revista Brasileira de Sementes, 34(1), 164-170. https://doi. org/10.1590/S0101-31222012000100020

Cosmo, N.L.; Gogosz, A.M.; Rego, S.S.; Nogueira, A.C. and Kuniyoshi, Y.S. (2017). Morfologia de fruto, semente e plântula, e germinação de sementes de Myrceugenia euosma (O. Berg) D. Legrand Myrtaceae). Floresta, 47(4), 479-488. http://dx.doi.org/10.5380/rf.v47i4.46933

Cremonez, P.A., Feroldi, M., Feiden, A., Rossi, E.D., Nadaleti, W.C. and Antonelli, J. (2013). Tremoço: Manejo e aplicações. Acta Iguazu, 2, 98-108.

Duarte, M.M.; Milani, J.E.F.; Blum, C.T. and Nogueira, A.C. (2015). Germinação e morfologia de sementes e plântulas de Albizia edwallii (Hoehne) Barneby \& J. W. Grimes. Revista Caatinga, 28 (3), 166-173. https://doi.org/10.1590/198321252015v28n319rc

Elbandy, M. and Rho, J. (2014). New flavone-diC-glycosides from the seeds of Egyptian lupin (Lupinus termis). Phytochem Lett, 9, 127-131. https://doi.org/10.1016/j.phytol.2014.05.006

Guedes, R.S.; Alves, E.U.; Santos-Moura, S.S.; Costa, E.G. and Melo, P.A.F.R. (2013). Tratamentos para superar dormência de sementes de Cassia fistula L. Biotemas, 26(4), 11-22, 2013. https:// doi.org/10.5007/2175-7925.2013v26n4p11 
Kerbauy, G.B. (2008). Fisiologia Vegetal. Rio de Janeiro: Guanabara Koogan.

Lessa, B.F.T.; Ferreira, V.M.; Araújo Neto, J.C. and Souza, R.C. (2013). Germinação de sementes de Emilia coccinea (Sims) G. DON em função da luminosidade, temperatura, armazenamento e profundidade de semeadura. Semina, 34(6), suplemento $1,3193-3204$. http://dx.doi. org/10.5433/1679-0359.2013v34n6Supl1p3193

Maguire, J.D. (1962). Speed of germination - aid in selection and evaluation for seedling emergence and vigor. Crop Science, 2(2), 176-177.

Marcos Filho, J. (2015). Fisiologia de sementes de plantas cultivadas. Londrina: ABRATES.

Martínez-Alcalá, I.; Walker, D.J. and Bernal, M.P. (2010). Chemical and bio-logical properties in the rhizosphere of Lupinus albus alter soil heavy metal fractionation. Ecotoxicology Environmental Safety, 73, 595-602. https://doi.org/10.1016/j. ecoenv.2009.12.009

Ministério da Agricultura. (2009). Regras para análise de sementes. Ministério da Agricultura, Pecuária e Abastecimento, Brasília.

Miranda, C.C.; Souza, D.M.S.; Manhone, P.R.; Oliveira, P.C. and Breier, T.B. (2012). Germinação de sementes de Anadenanthera peregrina (L.) Speg. com diferentes substratos em condições laboratoriais. Floresta e Ambiente, 19(1), 26-31. http://dx.doi.org/10.4322/floram.2012.004

Oliveira, A.B. and Bosco, M.R.O. (2013). Biometria, determinação da curva de absorção de água em sementes e emergência inicial de plântulas de Copernicia hospita Martius. Revista Brasileira de Agroecologia, 8(1), 66-74.

Paim, L.P.; Avrella, E.D.; Luchesse, J.; Freitas, E.M.; Lazarotto, M. and Fior, C.S. (2019). Seed analysis of Lupinus albescens Hook. \& Arn. Iheringia, Série Botânica, 74, e2019010. https://doi. org/10.21826/2446-82312019v74e2019010

Pereira, M.O.; Souza-Leal, T.; Lagazzi, G. and Pedroso-de-Moraes, C. (2011). Avaliação de métodos de escarificação na superação de dormência de Schizolobium parahyba (Vell.) Blake (Fabaceae: Caesalpinoideae). Revista em Agronegócio e Meio Ambiente, 4, 119-129.
Pilau, F.G.; Somavilla, L.; Battisti, R.; Schwerz, L. and Kulczynski, S.M. (2012). Germinação de sementes de crambe em diferentes temperaturas e substratos. Semina: Ciências Agrárias, 33(5), 1825-1830. http://dx.doi.org/10.5433/16790359.2012 v33n5p1825

Pinheiro, M. and Miotto, S.T.S. (2001). Flora ilustrada do Rio Grande do Sul, Legumonisae: Faboideae, gênero Lupinus L., number sixty. Universidade Federal do Rio Grande do Sul, Porto Alegre.

Portes, R.G.R.; Silva, F.D.; Silva, U.E.S. and Salvi, J.S. (2018). Curva de embebição e interferência da luz na germinação de sementes de rosa-dodeserto (Adenium obesum (Forssk.), Roem. \& Schult.). South American Journal of Basic Education, 5(1), 9-19.

Rovedder, A.P.M.; Eltz, F.L.F.; Drescher, M.S.; Dorneles, F.O. and Schenato, R.B. (2010). Espaçamento entre linhas e densidade de semeadura em revegetação com espécie de tremoço visando à recuperação de solo degradado. Ciência Rural, 40(9), 1955-1960. https://doi.org/10.1590/ S0103-84782010005000135

Santos, A.R.F.; Silva-Mann, R. and Ferreira, R.A. (2011). Water pre-hydration as priming for Moringa oleifera Lam. seeds under salt stress. Tropical and Subtropical Agroecosystems, 14(1), 201-207.

Shimizu, E.S.C.; Pinheiro, H.A.; Costa, M.A. and Filho, B.G.S. (2011). Aspectos fisiológicos da germinação e da qualidade de plântulas de Schizolobium amazonicum em resposta à escarificação das sementes em lixa e água quente. Revista Árvore, 35, 791-800. https://doi.org/10.1590/ S0100-67622011000500004

Silva, J.B. and Nakagawa, J. (1995). Estudos de fórmulas para cálculo de velocidade de germinação. Abrates, 5, 62-73.

Taiz, L.; Zeiger, E.; Moller, I.M. and Murphy A. (2017). Fisiologia e desenvolvimento vegetal. Porto Alegre: Artmed.

Zucareli, V.; Amaro, A.C.E.; Silvério, E.V. and Ferreira, G. (2010). Métodos de superação da dormência e temperatura na germinação de sementes de Dioclea violácea. Semina, 31, suplemento 1 , 1305-1312. http://dx.doi.org/10.5433/16790359.2010v31n4Sup1p1305 
Luciana Pinto Paim, Eduarda Demari Avrella, Juliana Carolina Alves Horlle, Claudimar Sidnei Fior,

Response of lupinus bracteolaris seeds to pre-germinative treatments and experimental conditions

Conflicto de Intereses Los autores declaran no tener ningún conflicto de intereses

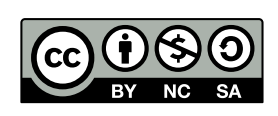

Licencia de Creative Commons

Revista de Investigación Agraria y Ambiental is licensed under a Creative Commons

Reconocimiento-NoComercial-CompartirIgual 4.0 Internacional License. 